\title{
THE INFLUENCE OF NUTRITION COUNSELING ON THE KNOWLEDGE AND INTAKE OF MACRO NUTRIENT WUS KEK IN REGION WORK PUSKESMAS SAWAH LEBAR BENGKULU
}

\author{
Meili Dwi Ananda' ${ }^{1}$, Jumiyati ${ }^{1)}$, dan Emy Yuliantini' ${ }^{1)}$ \\ ${ }^{1}$ Jurusan Gizi, Poltekkes Kemenkes Bengkulu, Jl. Indragiri No. 03, Kota Bengkulu, 38225 \\ E-mail: meilidwiananda@gmail.com
}

Submited: 8 October 2018 ; Accepted: 10 October 2019

https://doi.org/10.36525/sanitas.2019.4

\begin{abstract}
Women of Childbearing Age (WUS) are a population that is particularly interest in the prevention of nutritional problems, especially in addressing their Lack of Chronic Energy (KEK). KEK in WUS is very likely to result in a difficult childbirth and post partum hemorrhage as well as an increased risk death of the mother and of low birth weight babies. Data WUS SEZ in Indonesia in $2010(30,9 \%)$ increased in 2013 $(46,4 \%)$. Sixteen provinces with the prevalence of the risk of SEZ above the national province, namely the Bengkulu Province (15\%). The purpose of this study is to determine the effect of nutrition counseling on the knowledge and intake of macro nutrient on WUS SEZ in the working area of Health Center of Sawah Lebar the Width of the City of Bengkulu the Year 2018. The results of this study there was significant influence of nutritional counseling $(\mathrm{p}=0.000)$ on the intake of macro nutrient $(\mathrm{p}=0.000)$. On WUS KEK in the working area of Health Center of Sawah Lebar the width of the city of bengkulu the year 2018. The Design of this Research is Pre Experimental Design with design One Group Pretest-Posttest. Nutrition counseling on WUS KEK performed 3 times during 3 weeks. The number of samples as many as 23 people. Statistical analysis using dependent t-test and wilcoxon test.
\end{abstract}

Keywords: nutrition counseling, knowledge, intake of macro nutrient

\section{PENGARUH KONSELING GIZI TERHADAP PENGETAHUAN DAN ASUPAN ZAT GIZI MAKRO WUS KEK DI WILAYAH KERJA PUSKESMAS SAWAH LEBAR KOTA BENGKULU}

\begin{abstract}
ABSTRAK
Wanita Usia Subur (WUS) merupakan sasaran yang paling tepat dalam pencegahan masalah gizi terutama Kekurangan Energi Kronis (KEK). Jika terjadi KEK pada WUS akan mengakibatkan partus lama dan pendarahan pasca persalinan bahkan kematian ibu dan beresiko melahirkan bayi BBLR. Data WUS KEK di Indonesia pada tahun 2010 adalah 30,9\% dan mengalami peningkatan menjadi 46,4\% pada tahun 2013. Enam belas provinsi dengan prevalensi resiko KEK diatas nasional salah satunya yaitu Provinsi Bengkulu $(15 \%)$. Tujuan penelitian ini untuk mengetahui pengaruh konseling gizi terhadap pengetahuan dan asupan zat gizi makro pada WUS KEK di wilayah kerja Puskesmas Sawah Lebar Kota Bengkulu Tahun 2018. Design penelitian ini adalah Pre Ekperimental Design dengan menggunakan pendekatan One Group Pretest-Posttest. Konseling gizi pada WUS KEK dilakukan 3 kali selama 3 minggu. Jumlah subjek uji adalah 23 orang. Analisis statistik menggunakan Uji T-test Dependent dan Uji Wilcoxon. Hasil penelitian menunjukkan ada pengaruh signifikan antara konseling gizi dengan pengetahuan $(\mathrm{p}=0,000)$ dan asupan zat gizi makro $(\mathrm{p}=$
\end{abstract}


0,000). Sehingga ada pengaruh konseling gizi terhadap pengetahuan dan asupan zat gizi makro pada WUS KEK di wilayah kerja puskesmas sawah lebar kota bengkulu tahun 2018.

Kata Kunci: konseling, pengetahuan, asupan zat gizi makro

\section{PENDAHULUAN}

Wanita Usia Subur (WUS) dikatakan KEK apabila Lingkar Lengan Atas (LILA) $<23,5$ cm. Kekurangan Energi Kronis (KEK) merupakan keadaan seseorang atau WUS yang menderita kekurangan asupan makan dari zat gizi makro yang sudah berlangsung lama.(1) Ada beberapa faktor penyebab KEK salah satunya pendidikan ibu dan pola konsumsi makan. Pendidikan mempengaruhi tingkat pengetahuan seseorang. Pengetahuan menjadi penentu akan pemilihan makanan dan asupan yang dikonsumsi.(2)

KEK pada masa usia subur beresiko menurunkan kekuatan otot yang membantu proses persalinan sehingga dapat mengakibatkan terjadinya portus lama dan pendarahan pasca persalinan bahkan kematian ibu. Selain itu dapat mengakibatkan persalinan sulit dan lama, persalinan sebelum waktunya dan pendarahan, abortus atau keguguran, bayi lahir mati, neonatal, cacat bawaan, melahirkan BBLR (3). Wanita usia subur (WUS) merupakan wanita dengan keadaan reproduksinya yang berfungsi dengan baik antara umur 20-45 tahun. Jumlah Wanita Usia Subur (WUS) yang terbesar di Asia Tenggara adalah Indonesia (65\%), kemudian diikuti Vietnam (25,3\%) dan Filipina (23\%).(4)

Berdasarkan data(5) proporsi WUS dengan KEK di Indonesia pada usia 15-19 tahun pada tahun 2007 dan 2010 tetap yaitu 30,9\%, dan mengalami peningkatan pada tahun 2013 menjadi 46,6\%. Di Wilayah Sumatera prevalensi KEK tertinggi yaitu di Kepulauan Riau $(25,4 \%)$, setelah itu Bengkulu (23,7\%). Menurut data Dinas Kesehatan Kota Bengkulu (2016) didapatkan jumlah Ibu hamil KEK di Puskesmas Sawah Lebar Kota Bengkulu sebanyak 42 orang. Meningkatnya kebutuhan gizi seseorang salah satunya disebabkan kekurangan energi kronis (KEK) dan kehamilan. Peningkatan zat gizi tersebut diperlukan untuk perubahan komposisi dan metabolisme tubuh ibu, pertumbuhan dan perkembangan janin serta pertambahan besar organ kandungan(6).

Asupan zat gizi yang meningkat berperan penting dalam mempersiapkan kehamilan selanjutnya dan untuk meningkatkan status gizi. WUS yang mengalami KEK, berisiko gizi 
janin tidak baik dan akan melahirkan bayi yang BBLR. Bayi yang BBLR berpengaruh pada IMR (Infant Mortality Rate), perkembangan mental terhambat, dan risiko penyakit kronis pada usia dewasa.(7)

WUS yang menderita KEK disebabkan karena kurangnya pengetahuan, dan asupan zat gizi makro. Meningkatnya pengetahuan dan asupan zat gizi makro pada masalah WUS KEK perlu ditangani, salah satunya dengan cara memberikan konseling gizi. Menurut penelitian mengatakan bahwa intensitas konseling mempengaruhi peningkatan pengetahuan. Informasi atau pengetahuan yang dilakukan secara berulang-ulang dapat meningkatan pengetahuan seseorang.(8)

Pengetahuan yang rendah menyebabkan asupan zat gizi kurang dari kebutuhan gizi. Asupan zat gizi dapat meningkat setelah diberikan konseling gizi. Data penelitian menunjukkan bahwa ada pengaruh konseling gizi terhadap asupan energi dan protein pada ibu kekurangan energi kronis (KEK). Terjadi peningkatan rata-rata konsumsi energi setelah diberikan konseling gizi dari 57,5\% menjadi $69,4 \%$. Rata-rata asupan protein juga mengalami peningkatan dari 70,5\% menjadi 87,4\% setelah diberikan konseling gizi. (9)

Sejalan dengan penelitian lain yang menunjukkan bahwa terjadi peningkatan asupan karbohidrat setelah diberikan konseling gizi yaitu dari 22 responden (40\%) menjadi 39 responden $(70,9 \%)$. Pada asupan lemak juga terjadi peningkatan sebelum diberikan edukasi gizi 11 responden (20\%) dan meningkat menjadi 28 responden (50,9\%) setelah diberikan edukasi gizi.(10)

Setelah dilakukan survei awal pada WUS KEK di Puskesmas Sawah Lebar didapatkan hasil ternyata hanya 1 orang (10\%) responden yang berpengetahuan baik, dan 9 orang (90\%) responden masih berpengetahuan kurang. Sedangkan pada asupan energi dan zat gizi makrodari 10 orang responden didapatkan rata-rata asupan energi 1129,5 kkal/hr,asupan karbohidrat $144 \mathrm{~g} / \mathrm{hr}$, asupan protein 39,2 $\mathrm{g} / \mathrm{hr}$ dan asupan lemak 46,1 $\mathrm{g} / \mathrm{hr}(<80 \% \mathrm{AKG})$.

Berdasarkan uraian tersebut, peneliti tertarik untuk melakukan penelitian mengenai pengaruh konseling gizi terhadap pengetahuan, asupan energi dan zat gizi makro pada Wanita Usia Subur (WUS) Kekurangan Energi Kronis (KEK) di wilayah kerja Puskesmas Sawah Lebar Kota Bengkulu Tahun 2018. 


\section{METODE PENELITIAN}

Penelitian ini menggunakan design Pre Experimental Design dengan rancangan One Group Pretest-Posttest Design. Dilaksanakan pada bulan Maret - April 2018, intervensi berupa konseling dengan menggunakan media booklet. Populasi dalam penelitian ini adalah seluruh wanita usia subur (WUS) yang mengalami Kekurangan Energi Kronis (KEK)yang ada di Wilayah Kerja Puskesmas Sawah Lebar sebanyak 42 orang. Sampel dalam penelitian ini berjumlah 23 orang. Tekhnik pengambilan sampel dengan cara purposive sampling.

Variabel yang diteliti yaitu pengetahuan dan asupan zat gizi makro (energi, karbohidrat, protein, dan lemak). Tingkat pengetahuan diukur dengan menggunakan kuesioner serta data asupan makan responden dengan wawancara menggunakan form food recall. Analisis statistik menggunakan uji t-test dependent dan uji wilcoxon.

\section{HASIL DAN PEMBAHASAN}

\section{Analisis Univariat}

Tabel 1. Distribusi Frekuensi Pengetahuan WUSKEK di Wilayah Kerja Puskesmas Sawah Lebar Kota Bengkulu

\begin{tabular}{llrrlllr}
\hline Variabel & $\mathbf{n}$ & \multicolumn{2}{c}{ Pre Test } & \multicolumn{4}{c}{ Post Test } \\
\cline { 2 - 8 } & & Min & Max & Mean \pm SD & Min & Max & Mean \pm SD \\
\hline Pengetahuan & 23 & 20 & 87 & $60,6 \pm 15,2$ & 73 & 100 & $88,3 \pm 7,2$ \\
\hline
\end{tabular}

Berdasarkan Tabel 1 dapat diketahui bahwa nilai minimal pengetahuan responden pada pre test yaitu 20 dan maksimal 87, terjadi peningkatan nilai minimal post test yaitu 73 dan maksimal 100, sedangkan rata-rata pengetahuan responden setelah diberikan konseling gizi mengalami peningkatan dari 60,6 menjadi 88,3.

Tabel 2. Distribusi Frekuensi Asupan Zat Gizi Makro Wanita Usia Subur (WUS) Kekurangan Energi Kronis (KEK) di Wilayah Kerja Puskesmas Sawah Lebar Kota Bengkulu

\begin{tabular}{llllllll}
\hline Variabel & \multirow{2}{*}{} & \multicolumn{2}{c}{ Pre Test } & \multicolumn{4}{c}{ Post Test } \\
\cline { 3 - 8 } & & Min & Max & Mean \pm SD & Min & Max & Mean \pm SD \\
\hline Energi & 23 & 1173,5 & 1838,2 & $1422,2 \pm 188,4$ & 1692,6 & 2567,4 & $1991,5 \pm 198$ \\
& & & & & & &, 5 \\
\hline Karbohidrat & 23 & 116,5 & 269,1 & $174,5 \pm 38,5$ & 117,1 & 363,9 & $225,7 \pm 54,6$ \\
\hline
\end{tabular}




\begin{tabular}{lccccccc}
\hline Protein & 23 & 35,6 & 80,5 & $52,3 \pm 9,9$ & 44,3 & 126,7 & $80,4 \pm 15,0$ \\
\hline Lemak & 23 & 35,7 & 80,6 & $60,7 \pm 11,7$ & 64,7 & 101 & $85,7 \pm 10,2$ \\
\hline
\end{tabular}

Berdasarkan Tabel 2 dapat diketahui bahwa nilai rata-rata asupan zat gizi makro responden mengalami peningkatan setelah diberikan konseling gizi, seperti pada asupan energi mengalami peningkatan dari 1422,2 kkal menjadi 1991,5 kkal. Rata-rata asupan karbohidrat responden mengalami peningkatan dari 174,5 gram menjadi 225,7 gram. Selain asupan energi dan karbohidrat terdapat asupan protein dan lemak, rata-rata asupan protein dan lemak responden juga mengalami peningkatan yaitu dari 52,3 gram menjadi 80,4 gram pada asupan protein, serta dari 60,7 gram menjadi 85,7 gram pada asupan lemak.

\section{Analisis Bivariat}

Tabel 3. Perbedaan Pengetahuan Sebelum dan Sesudah Konseling Gizi pada Wanita Usia Subur (WUS) Kekurangan Energi Kronis (KEK)

\begin{tabular}{llll}
\hline Variabel & n & Mean \pm SD & $\boldsymbol{P}$ \\
\hline Pengetahuan & & & \\
Pre Test & 23 & $60,6 \pm 15,2$ & 0,000 \\
Post Test & 23 & $88,3 \pm 7,2$ & \\
\hline
\end{tabular}

Berdasarkan Tabel 3 dapat diketahui bahwa pengetahuan responden mengalami peningkatan sebesar 27,7. Hasil uji statistik didapatkan nilai $\mathrm{p}=0,000$ maka dapat disimpulkan bahwa ada pengaruh yang signifikan antara pengetahuan responden sebelum dan sesudah diberikan konseling gizi.

Tabel 4. Perbedaan Asupan Zat Gizi Makro Sebelum dan Sesudah Konseling Gizi pada Wanita Usia Subur (WUS) Kekurangan Energi Kronis (KEK)

\begin{tabular}{llll}
\hline Variabel & N & Mean \pm SD & $\boldsymbol{P}$ \\
\hline Asupan Energi & & & \\
Pre Test & 23 & $1422,2 \pm 188,4$ & 0,000 \\
Post Test & 23 & $1991,5 \pm 198,5$ & \\
\hline Asupan Karbohidrat & & & \\
Pre Test & 23 & $174,5 \pm 38,5$ & 0,000 \\
Post Test & 23 & $225,7 \pm 54,6$ & \\
Asupan Protein & & & \\
Pre Test & 23 & $52,3 \pm 9,9$ & 0,000 \\
\hline
\end{tabular}


Post Test

23

$80,4 \pm 15,0$

Asupan Lemak

Pre Test

$60,7 \pm 11,7$

0,000

Post Test

23

$85,7 \pm 10,2$

Berdasarkan Tabel 4 dapat diketahui bahwa asupan energi responden mengalami peningkatan sebesar 569,3 kkal. Hasil uji statistik didapatkan nilai $\mathrm{p}=$ 0,000 maka dapat disimpulkan bahwa ada pengaruh yang signifikan antara asupan energi responden sebelum dan sesudah diberikan konseling gizi.

Hasil uji statistik pada asupan karbohidrat, protein, dan lemak juga mengalami peningkatan secara berurutan yaitu 51,2 gram, 28,1 gram, dan 25 gram. Hasil uji statistik untuk ketiga variabel didapatkan hasil yang sama yaitu nilai $\mathrm{p}=0,000$ maka dapat disimpulkan bahwa ada pengaruh yang signifikan antara asupan karbohidrat, protein, dan lemak responden sebelum dan sesudah diberikan konseling gizi.

\section{PEMBAHASAN}

\section{Pengetahuan Gizi}

Berdasarkan hasil penelitian ada pengaruh pengetahuan sebelum dan sesudah diberikan konseling gizi. Hal ini dapat dilihat dari peningkatan rata-rata pengetahun setelah diberi konseling gizi sebesar 27,7. Berdasarkan hasil wawancara pengetahuan sebagian besar responden mempunyai pengetahuan yang kurang mengenai Kekurangan Energi Kronis (KEK). Dari 15 responden banyak yang tidak mengetahui definisi (60,9\%), ukuran LILA KEK (52\%), dampak KEK (52\%), frekuensi sumber protein hewani (21,7\%), porsi protein hewani dalam sekali makan $(26 \%)$, jumlah porsi per hari sumber protein hewani $(17,4 \%)$, hingga resiko jarak kehamilan $(34,8 \%)$.

Setelah diberikan konseling gizi terjadi peningkatan pengetahuan dengan rata-rata nilai 88,3. Akan tetapi, masih ada beberapa soal yang banyak dijawab salah oleh responden, seperti soal tentang frekuensi sumber protein hewani $(65 \%)$, porsi protein hewani dalam sekali makan (52\%) dan porsi protein hewani dalam sehari (47,8\%). Responden masih susah untuk menghitung porsi yang sesuai dengan anjuran, sehingga perlu dilatih lagi agar responden mudah memahami dan menerapkannya pada kehidupan sehari-hari. 
Salah satu penyebab pengetahuan responden kurang yaitu karena pendidikan terakhir dan pekerjaan responden. Mayoritas pendidikan terakhir WUS KEK yaitu tamatan SMA (47,8\%). Hasil dari penelitian mengatakan bahwa ibu yang berpendidikan rendah cenderung mengalami KEK. (11)

Pengetahuan akan semakin baik diiringi dengan tingkat pendidikan seseorang. Semakin tinggi pendidikan maka semakin mudah seseorang untuk menerima informasi (Mubarak, 2011). Pengetahuan merupakan hasil pengideraan manusia, atau hasil tahu seseorang terhadap objek melalui indera yang dimilikinya sehingga terjadi perubahan pengetahuan dikarenakan adanya perubahan pola pikir dan bertambahnya pengetahuan tersebut.(12)

Menurut penelitian mengatakan bahwa terdapat peningkatan pengetahuan pada ibu setelah diberikan pendidikan kesehatan dengan media booklet. ${ }^{13,14}$ Penelitian ini selaras dengan penelitian yang mengatakan bahwa terdapat peningkatan pengetahuan yang lebih besar pada kelompok wanita usia subur yang mendapatkan pendidikan kesehatan dengan media booklet daripada wanita usia subur yang mendapatkan pendidikan kesehatan dengan metode ceramah tanpa media booklet.(13)

\section{Asupan Zat Gizi Makro}

Berdasarkan hasil penelitianada pengaruh asupan zat gizi makro sebelum dan sesudah diberikan konseling gizi. Hal ini dapat dilihat dari peningkatan rata-rata asupan zat gizi makro (energi, karbohidrat, protein dan lemak) setelah diberi konseling gizi secara berurutan yaitu 569,3 kkal, 51,2 gram, 28,1 gram, dan 25 gram.

Hasil penelitian ini diketahui bahwa asupan zat gizi makro responden sebelum diberikan konseling gizi kurang dari $\mathrm{AKG}$, dikarenakan porsi makan responden yang sedikit. Banyak responden mengaku sudah merasa kenyang dengan asupan makan yang sedikit. Alasan lainnya juga dikarenakan ada beberapa responden yang masih tinggal dengan orang tua sehingga mereka merasa tidak enak apabila mengambil makanan dalam porsi banyak.

Faktor lain juga dikarenakan porsi makan yang sedikit dan kurang bervariasi. Banyak responden mengaku bahwa belum mengetahui porsi yang sesuai dengan kebutuhan, sehingga mengonsumsi makanan tidak sesuai porsi hanya sesuai dengan keinginan mereka sendiri. Setelah diberikan konseling gizi, responden mulai memahami pentingnya porsi 
makan yang sesuai dengan kebutuhan responden sebagai penunjang peningkatan berat badan sehingga asupan makan meningkat.Responden mulai sering mengonsumsi snack pada saat selingan, hal ini yang menjadi salah satu pendorong asupan energi responden menjadi meningkat.

Asupan yang dikonsumsi harus sesuai dengan kebutuhan karena asupan berperan penting dalam mempersiapkan kehamilan selanjutnya dan untuk meningkatkan status gizi. Apabila WUS mengalami KEK, berisikogizi janin tidak baik dan akan melahirkan bayi yang BBLR. Bayi yang BBLR berpengaruh pada IMR (Infant Mortality Rate), perkembangan mental terhambat, dan risiko penyakit kronis pada usia dewasa.(7)

Hasil penelitian ini diketahui bahwa asupan energi WUS KEK kurang dari Angka Kecukupan Gizi (AKG). Menurut AKG, WUS membutuhkan asupan energi sebesar 2250 kkal. Energi merupakan hasil metabolisme protein, lemak dan karbohidrat. Energi diperlukan tubuh untuk pertumbuhan, metabolisme, utilisasi bahan makanan dan aktivitas. Energi yang masuk melalui makanan harus seimbang dengan kebutuhan. Ketidakseimbangan masukan energi dengan kebutuhan yang berlangsung dalam jangka waktu lama dapat menimbulkan masalah gizi.(15)

Setelah diberikan konseling gizi rata-rata asupan energi responden meningkat dari 1422,2 kkal menjadi 1991,5 kkal. Sejalan dengan penelitian yang mengatakan bahwa adanya pengaruh pemberian konseling gizi terhadap perubahan asupan energi $(\mathrm{p}<0,05)$. Penelitian tersebut menunjukkan bahwa kelompok perlakuan (56\%) dan kelompok kontrol (50\%) mengalami peningkatan asupan energi mencapai $80 \%$, ditandai dengan pasien dalam memilih makanan padat energi sehingga pasien mampu mengantisipasi gejala infeksi yang mungkin timbul dengan cara mengonsumsi makanan yang sesuai dengan kebutuhan dan penyakitnya.(16)

Begitu juga untuk kebutuhan karbohidrat, menurut AKG WUS membutuhkan asupan karbohidrat sebesar 309 gram. Karbohidrat menyediakan energi tubuh dan karbohidrat diperlukan bagi kelangsungan proses metabolisme lemak. Karbohidrat yang berlebih akan disimpan dalam bentuk glikogen sebagai energi siap pakai pada saat tubuh mengalami kekurangan.(17) 
Setelah diberikan konseling gizi rata-rata asupan karbohidrat meningkat yaitu dari 175,5 gram menjadi 225,7 gram. Sejalan dengan penelitian ${ }^{10}$ menunjukkan bahwa terjadi peningkatan asupan karbohidrat setelah diberikan konseling gizi yaitu dari 22 responden (40\%) menjadi 39 responden (70,9\%), dibuktikan dengan hasil nilai $\mathrm{p}<0,05$.

Asupan protein sebelum diberikan konseling gizi juga kurang dari AKG. Menurut AKG WUS membutuhkan asupan protein sebesar 56 gram. Setelah diberikan konseling gizi asupan protein responden meningkat menjadi 125,7 gram. Hal ini dikarenakan responden mulai memahami bahwa asupan protein penting untuk WUS yang mengalami KEK.

Apabila asupan protein semakin kecil maka risiko kejadian KEK semakin besar demikian juga sebaliknya. Hasil ini mengindikasikan bahwa peran protein dalam membangun struktur jaringan tubuh menjadi bagian akhir untuk menyuplai kebutuhan energi pada saat asupan karbohidrat dan lemak berkurang. Asupan lemak dan karbohidrat sebagai pembanding asupan protein dalam perannya sebagai sumber energi alternative.(18)

Protein mempunyai fungsi khas yang tidak dapat digantikan oleh zat lain yaitu membangun serta memelihara sel-sel dan jaringan tubuh.(19) Asupan proteinyang cukup berkaitan dengan gizi normal yaitu memperkecil faktor risiko terjadinya kurang energi kronis yang berhubungan dengan LILA. Terkait dengan tingkat kecukupan konsumsi protein maka protein akan berfungsi sebagai energi alternatif yang menunjukan dominasi protein sebagai sumber energi akan dilakukan sebagai kompensasi apabila terjadi defisit energy.(20)

Menurut penelitian mengatakan bahwa seseorang mengalami kekurangan gizi khususnya asupan protein kurang maka akan memiliki peluang lebih besar untuk mengalami KEK. Secara teoritis, asupan protein berhubungan dengan ukuran lingkar lengan atas, jika asupan protein cukup, maka akan berfungsi sebagai energi alternatif terakhir setelah karbohidrat dan lemak terpakai karena protein sebagai multifungsi yaitu dapat memelihara jaringan tubuh serta meningkatkan pertumbuhan organ tubuh.(21)

Begitu juga dengan hasil asupan lemak yang kurang dari AKG. Menurut AKG WUS membutuhkan asupan lemak sebesar 75 gram. Setelah diberikan konseling gizi rata-rata asupan lemak responden mengalami peningkatan menjadi 101 gram. Responden sering mengonsumsi snack yang mengandung tinggi lemak pada saat selingan seperti gorengan, 
pempek, batagor. Hal ini yang menjadi salah satu pendorong asupan lemak responden meningkat.

Penelian tersebut didukung dengan penelitian(22) yang mengatakan bahwa ada pengaruh konseling gizi dengan penurunan rata-rata asupan lemak. Hal ini ditandai dengan hasil $(\mathrm{p}<0,05)$ yang artinya terdapat penurunan rata-rata asupan lemak jenuh sebelum dan sesudah diberikan konseling gizi.

\section{SIMPULAN}

Berdasarkan hasil penelitian dapat disimpulkan bahwa nilai rata-rata pengetahuan dan asupan zat gizi makro setelah diberikan konseling gizi mengalami peningkatan. Ada pengaruh konseling gizi terhadap pengetahuan dan asupan zat gizi makro responden sebelum dan setelah diberikan konseling gizi pada WUS KEK, ditandai dengan hasil $\mathrm{p}=$ $0,000(\mathrm{p}<0,05)$.

\section{UCAPAN TERIMA KASIH}

Penulis mengucapkan terima kasih kepada pembimbing dan penguji yang telah memberikan saran yang bersifat membangun sehingga skripsi ini dapat diselesaikan.

\section{DAFTAR PUSTAKA}

1. Rahmaniar A, Taslim NA, dan Bahar B. Media Gizi Masyarakat Indonesia. Faktorfaktor yang Berhubungan dengan Kekurangan Energi Kronis pada Ibu Hamil di Tampa Padang, Kabupaten Mamuju, Sulawesi Barat. 2013 Feb;2(7): 98-03.

2. Mubarak W. 2011. Promosi Kesehatan Untuk Kebidanan. Salemba Medika: Jakarta; 2012.

3. Kemenkes RI. 2015. Pedoman Penanggulangan Kurang Energi Kronik (KEK) pada Ibu Hamil. Depok: Direktorat Bina Gizi Direktorat Jenderal Bina Gizi dan Kesehatan Ibu dan Anak Kementerian Kesehatan RI. https://www.slideshare.net/patenpisan/finalorientasi-anc-terpadu-kirim-dir-10-agustus diakses tanggal 8 Februari 2018 Jam 04:42.

4. Family Planning Worldwide. Population Referention Bureau; 2008. 
5. Riskesdas. Badan Penelitian dan Pengembangan Kesehatan Kementerian Kesehatan RI; 2013.

6. Aminin F, Wulandari A, dan Lestari RP. Pengaruh Kekurangan Energi Kronis (KEK) dengan Kejadian Anemia pada Ibu Hamil. Jurnal Kesehatan. 2014 Okt;5(2):167-72.

7. Arisman MB. Gizi Dalam Daur Kehidupan. Jakarta: EGC; 2004.

8. Notoatmodjo S. Pendidikan dan Perilaku Kesehatan. Rineka Cipta:Jakarta;2003.

9. Yuniarti H, Boediman D, dan Sudargo T. Pengaruh Konseling Gizi Terhadap Status Gizi Ibu Hamil KEK pada Program JPS-BK di Kota Palembang. Jurnal Gizi Klinik Indonesia. 2005 Mar;1(3):103-07.

10. Thasim S, Syam A, dan Ulfah N. Pengaruh Edukasi Gizi Terhadap Perubahan Pengetahuan dan Asupan Zat Gizi Pada Anak Gizi Lebih di SDN Sudirman 1 Makassar Tahun 2013. 2013.

11. Wuryanti, Rantetampang AL, dan Hasmi. The Factors Affecting of Malnutrient Chronical Energy Protein to Pregnancy at Mappi General Hospital Sub Province Mappi. International Journal of Sciences: Basic and Applied Research (IJSBAR). 2017;35(1): 260-77.

12. Notoatmodjo, S. Metodelogi Penelitian Kesehatan. Jakarta: Rineka Cipta; 2012.

13. Pratiwi YF dan Puspitasari DI. Efektivitas Penggunaan Media Booklet Terhadap Pengetahuan Gizi Seimbang pada Ibu Balita Gizi Kurang di Kelurahan Semanggi Kecamatan Pasar Kliwon Kota Surakarta. Jurnal Kesehatan. 2017 Jun;10(1): 58-67.

14. Zulaekah S. Pendidikan Gizi Dengan Media Booklet Terhadap Pengetahuan Gizi. Jurnal Kesehatan Masyarakat. 2012;7(2):127-33.

15. Rokhmah F, Lailatul M dan Triska SN. Hubungan Tingkat Kecukupan Energi dan Zat Gizi Makro dengan Status Gizi Siswi SMA di Pondok Pesantren AL-Izzah Kota Batu. Media Gizi Indonesia. 2016 Jun;1(11): 94-00.

16. Yuniarti, Purba M, dan Pangastuti R. Pengaruh Konseling Gizi dan Penambahan Makanan Terhadap Asupan Zat Gizi dan Status Gizi Pasien HIV/AIDS. Jurnal Gizi Klinik Indonesia. 2013 Jan;9(3):132-38.

17. Waryana. Gizi Reproduksi. Yogyakarta: Pustaka Rahima; 2010.

18. Depkes. Gizi dan Kesehatan Masyarakat. Jakarta: PT Raja Grafindo Persada; 2007. 
19. Almatsier S. Prinsip Ilmu Gizi Dasar. Jakarta: PT Gramedia Pustaka Utama; 2001.

20. Guyton dan Hall. Bahan Ajar Fisiology Kedokteran. Jakarta: EGC; 2008.

21. Marsedi G, Widajanti L, dan Aruben R. Hubungan Sosial Ekonomi dan Asupan Zat Gizi dengan Kejadian Kurang Energi Kronik (KEK) pada Ibu Hamil di Wilayah Puskesmas Sei Jang Kecamatan Bukit Bestari Kota Tanjung Pinang Tahun 2016. Jurnal Kesehatan Masyarakat (e-journal). 2017 Jul;5(3):138-47.

22. Lestari E. dan Dieny FF. Pengaruh Konseling Gizi Sebaya Terhadap Asupan Serat dan Lemak Jenuh pada Remaja Obesitas di Semarang. Jurnal of Nutrition College. 2016;5(1):36-43. 